\title{
Phet Simulation Software-Based Learning to Improve Understanding Ability in Light Concept
}

\author{
Rudi Haryadi $^{1}$, Heni Pujiastuti ${ }^{2}$ \\ \{rudiharyadi@untirta.ac.id ${ }^{1}$, henipujiastuti@untirta.ac.id ${ }^{2}$ \} \\ Universitas Sultan Ageng Tirtayasa, Indonesia ${ }^{12}$
}

\begin{abstract}
The purpose of this study is to determine the results of the application of the PhET Simulations media in understanding light matter while learning physics. The research made use of a randomized pretest and posttest control group design. The population of the study comprises of $67^{\text {th }}$ grade classes of Serang SMA. The research sample was made up of one experimental and control class each. The obtained results showed that the application of PhET Simulations on light material when learning the light concept in physics produced an $\mathrm{N}$-gain value that is $37 \%$ higher than using direct learning techniques. Hence, it can be concluded that the use of phet simulation softwarebased learning media, improves students' conceptual abilities in learning the concept of light material.
\end{abstract}

Keywords: Learning physics, media PhET Simulations, understanding student concepts

\section{Introduction}

Since the evolution of the $21^{\text {st }}$ century, science and technology has rapidly grown especially in the field of microelectronics engineering. This development has a major influence on various aspects of life, and human behavior; hence activities are now much more dependent on science and technology. The development and tremendous growth of science and technology has greatly influenced the world of education, especially in the learning process.

Technology is a media or learning tool that is beneficial to teachers and students owing to its efficiency and effectiveness in achieving competencies. Learning tools such as laptops, internet, LCD and others (both simple and modern) are very helpful for the effectiveness of the learning process. But the use of technology-based academic tools will be very useful if the teacher applies a student center knowledge technique [1].

Technology serves as a media or tool during the teaching and learning process. It doesn't just create a communication medium between the source (teacher) and the recipient (students), it is also an integral part of the education process [2]. The use of computer and computational devices is believed to increase results and students learning desire, which happens to be indicators of effectiveness and efficiency. Therefore the development of technology-based learning techniques is essential and must be carried out by the teacher [3].

Technology is a productive media used to educated students. As a learning component, technological tools (e.g. ICT), is associated with various activities used to access, collect, manipulate, and communicate information. Some of these tools are computers, laptops, 
software applications, circuits, the internet, wi-fi, local networking infrastructure and telecommunication. It use will make teaching and learning productive compelling and efficient as it enables a teacher to come across numerous educational materials and equipment that will help facilitate student understanding, present information more clearly, facilitate interpretation of data, and obtain information. As a result of this, technology can be defined as an invaluable, teaching and learning process [4].

Learning is the most important educational activity. Presently, the use of laptops and the internet is very helpful in the teaching and learning process as it tends to facilitate cognitive, effective and psychomotor development. The facilities provided by the system, enables students to learn independently, anytime and anywhere without being limited by space and time. The technology learning material tend to vary in the form of words, text, visual, audio, film, and animation [5].

The use of media is to facilitate teacher and student interaction, with the aim of helping students learn optimally. When students come across interesting and captivating media tools, understanding the subject matter will be a lot easier and it will have a positive impact on their learning outcomes. The media is very important tool used to attract students' interest in learning. There are various uses of computers that are currently being developed as media that can make students interested in education. The use of animations in learning, motivates students, helps to instill understanding on the subject matter. In addition to helping students to facilitate understanding of the teaching material it also provides meaningful experience and enhances their interest. [6].

Physics plays an important role in the development of science and technology. Physics can be defined as a compiled knowledge that is based on facts, natural phenomena, results of thought, and experiments. The development of science and technology affects almost all human lives in various fields. To be able to master it, the quality of human resources must be enhanced by improving the educational quality of learning in schools. To adjust to the era of globalization marked by developments in the field of technology, teachers should support technology-based education. To achieve this, the teacher is required to consider is how to organize learning, convey its contents, organize the interactions between existing academic resources in order to function optimally and achieve set educational goals.[7]. Therefore, learning strategies must be appropriately designed to strengthen students' conceptual knowledge obtained by using the PhET Simulations media and other technological tools.

PhET was created the science community through the PhET Project at the University of Colorado, USA. PhET an acronym for Physics Education Technology is a site that provides physics learning simulations that can be downloaded from the internet without charges and used for classroom teaching. PhET Colorado interactive simulation is a fun and interactive media simulation that can be used to clarify physics concepts with respect to light [8]. By using it, students are expected to be able to apply the concepts obtained during the theoretical and practical lecturer to simulations contained in the PhET media.

\section{Method}

The quasi-experimental method along with the randomized Pretest-Posttest Control Group Design was used in this research design. This research was conducted by treating the experimental group and comparing the control group. This design consisted of two groups, each of which was given a pretest and posttest using the phet simulation software-based 
learning method. Populations in this study were grade X students of mathematics and natural sciences at a high school in the city of Serang in the 2017/2018 academic year. A total of 4 classes with each class consisting of around 30 students were used. The sample from this study was selected using the randomized sampling class method. 20 multiple choice questions were used to understand and measure students' concepts of light given during the pretest and posttest stages.

\section{Result and Discuss}

The results of the data analysis are presented in Figure 1.

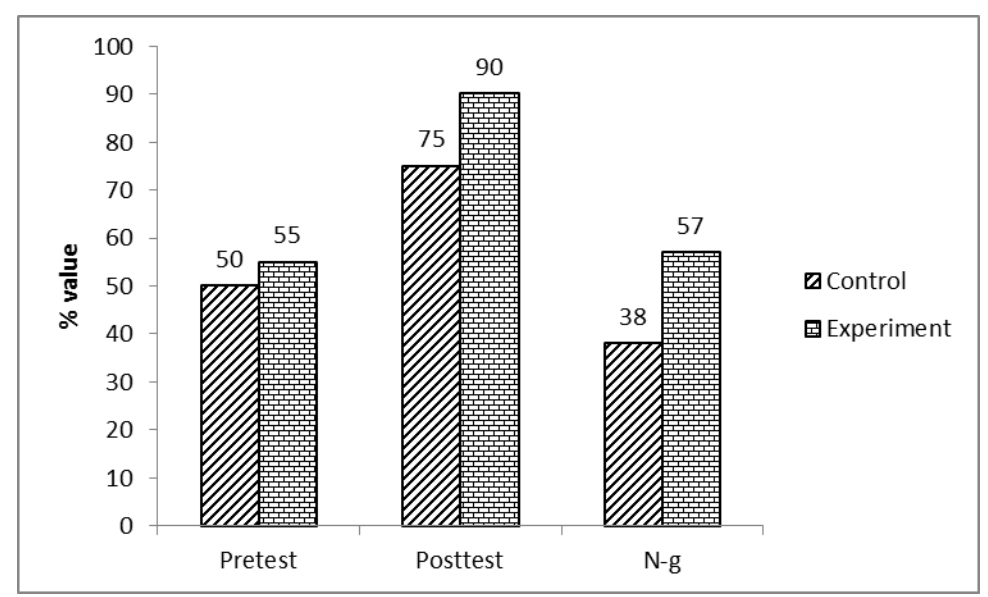

Fig. 1: Graphical comparison of the average value of the pretest, posttest and gain normalized understanding of students' concepts.

Based on the graph in Figure 1, it is seen that the percentage of normalized gain values $\langle\mathrm{N}-\mathrm{g}\rangle$ and the conceptual understanding of students in the experimental and control classes are 57 and 38 respectively. It is concluded that the conceptual understanding of former is higher than the later.

In detail, the comparison of the normalized gain values for understanding the light concept obtained by the experimental and control classes is presented in Figure 2. 


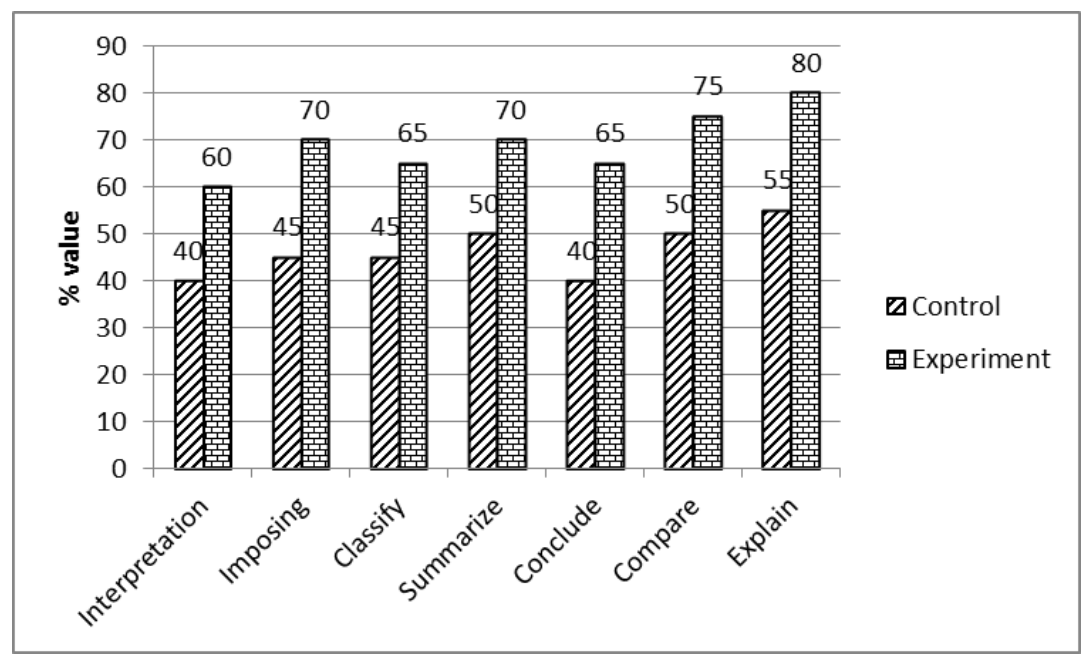

Fig. 2. Graph comparison of average N-gain values in each aspect of conceptual Understanding

Based on the graph in Figure 2, it can be seen that almost all aspects of conceptual understanding in the experimental class have a percentage of normalized gain values $\langle\mathrm{N}-\mathrm{g}\rangle$ higher than the control class. Therefore, it can be concluded that an increase in students' understanding of the concept using the phet simulation software is higher than the control class with direct learning. Based on the above data it can be stated that students who make use of the phet simulation software-based in learning are more likely to remember and explore concepts, acquire knowledge, and aspire higher. In addition, they can directly observe the variable changes made to the concepts learned. The simulation provided by phet is very interactive which invites students to learn by exploring directly, that way learning becomes more meaningful.

With the phet software-based learning simulation, students become more interested in carrying out the learning process. In addition, they are able to independently learn and understand on their own with the assistance of their parents or teachers. Phet simulation software-based learning can be accessed through the internet making it possible for students to repeat and carry out the learning technique irrespective of their time and location.

Computer simulation can be a solution if the equipment for real practicum does not exist in the school even though it could be very difficult for one to replace real practicum with a virtual practicum because the skills of students to use the equipment in practicum are actually better than students who only do virtual [9]. Therefore, with the help of phet software, which acts as a complement and supplement, students are facilitated in understanding the concepts they learn through independent findings.

\section{References}

[1] N. Pheeraphan, "Enhancement of the 21 st Century Skills for Thai Higher Education by Integration of ICT in Classroom," Procedia - Soc. Behav. Sci., vol. 103, pp. 365-373 (2013)

[2] N. Ongardwanich, S. Kanjanawasee, and C. Tuipae, "Development of 21 st Century 
Skill Scales as Perceived by Students," Procedia - Soc. Behav. Sci., vol. 191, pp. 737741 (2015)

[3] M. C. Sahin, "Instructional design principles for 21 st century learning skills," vol. 1, no. 1, pp. 1464-1468 (2009)

[4] M. Romero, "Work, games and lifelong learning in the 21 st century," Procedia Soc. Behav. Sci., vol. 174, pp. 115-121 (2015)

[5] T. Krobthong, "Teaching University Physics by using Interactive Science Simulations methods," Procedia - Soc. Behav. Sci., vol. 197, no. February, pp. 18111817 (2015)

[6] K. Su and S. Yeh, "Effective Assessments of Integrated Animations to Explore College Students ' Physics Learning Performances,” vol. 176, pp. 588-595 (2015)

[7] M. Demirel, "Lifelong learning and schools in the twenty-first century," vol. 1, no. 1, pp. 1709-1716 (2009)

[8] K. Perkins, W. Adams, M. Dubson, N. Finkelstein, S. Reid, and C. Wieman, "PhET : Interactive Simulations for Teaching and Learning Physics," vol. 18, no. 2006 (2012)

[9] J. Cuadros, C. Artigas, F. Guitart, and F. Martori, "Analyzing a virtual-lab based contextualized activity from action logs," Procedia - Soc. Behav. Sci., vol. 182, no. 1, pp. 441-447 (2015) 